\title{
SPOŁECZEŃSTWO BEZPIECZEŃSTWA JAKO KONSEKWENCJE ŻYCIA W PŁYNNYCH CZASACH
}

\begin{abstract}
Streszczenie: Artykuł porusza problematykę postaw i zachowań człowieka XXI wieku w perspektywie zagrożeń współczesnego świata wynikających z uwarunkowań „społeczeństwa sieci”. Znaczenie bezpieczeństwa jako naczelnej potrzeby człowieka w kontekście przemian społeczno-politycznych przełomu XX i XXI wieku i szybko rozwijających się technologii informacyjnych stanowi pretekst do sformułowania tezy o pojawieniu się specyficznie ukształtowanego społeczeństwa bezpieczeństwa. Publikacja ta jest próbą zrozumienia postaw i zachowań współczesnego człowieka ze szczególnym uwzględnieniem uwarunkowań związanych ze zmienną rzeczywistością społeczną.
\end{abstract}

Słowa kluczowe: bezpieczeństwo, postawy człowieka, społeczeństwo bezpieczeństwa, Internet, świat wirtualny, zagrożenia

\section{WSTĘP}

Sformułowanie „płynne czasy” zawdzięczamy Zygmuntowi Baumanowi (Bauman 2007). Opisane w tej publikacji sytuacje stanowią pewną podstawę do rozpoczęcia dyskusji, co dziś dla człowieka XXI wieku jest najważniejsze. Bo przecież, na przestrzeni wieków, społeczeństwa ludzkie rozwijały się w pewnych granicach, zarówno prawnych, jak etycznych czy w końcu ekonomicznych. To właśnie postawy społeczne kształtowały postępowanie całych narodów, a co za tym idzie - stawały się wyznacznikami narodowości czy patriotyzmu.

Dziś świat wygląda inaczej. Mamy oczywiście swoje ideały, wartości i poglądy. Czy one jednak czasem nie rozpływają się w płynnej mgle codzienności? Liczy się tylko dobro materialne, które - zdaje się - dziś stanowi dobro najwyższe. 
Gdzie zatem jesteśmy? Jak dziś wyglądają nasze potrzeby i oczekiwania? Czy człowiek coraz bardziej wolny jest coraz bardziej szczęśliwy? Czy postawa wolności od czegoś daje rzeczywiście poczucie szczęścia? Wydaje się, że nie. Bo dziś człowiek najbardziej potrzebuje stabilizacji i pewności. To być może dziś stanowi najwyższą wartość samą w sobie, choć być może nie do końca sami zdajemy sobie $\mathrm{z}$ tego sprawę.

Warto zastanowić się nad tymi pytaniami, bo znając zagrożenia, możemy im zapobiegać.

Człowiek, spoglądając w przeszłość i przyszłość, stara się sklasyfikować swoją pozycję względem cech lub zjawisk towarzyszących jego czasom. Stąd też mamy społeczeństwa industrialne, postindustrialne czy też postkonsumpcyjne. Zmiany są czymś naturalnym w rozwoju człowieka. Nawet wtedy, gdy z naszego punktu widzenia stanowią regres. Tak przecież stało się po 2008 roku, gdzie wszechobecny kryzys spowodował, że nagle przestaliśmy żyć dla konsumpcji. Jak zatem nazwać priorytety dzisiejszego człowieka, który już widział „sen amerykański”? Jakie to niesie skutki dla przyszłego człowieka?

Być może priorytetem dzisiaj jest bezpieczeństwo, które przysłoniło dotychczasowe cele. Nie bierzemy już kredytów na zakupy towarów, lecz kupujemy to, co niezbędne. Praca nie jest celem do uzyskania zdolności kredytowej, ale do przetrwania - zapewnienia bytu.

Bezpieczeństwo stało się wartością samą w sobie. Dziś młodzi ludzie chętnie garną się do pracy na przykład w Policji, choć jeszcze kilka lat temu było mało chętnych. Wynika to między innymi właśnie ze zmiany preferencji. Nie sama wysokość wynagrodzenia, ale poczucie bezpieczeństwa i stabilizacji jest wartością poszukiwaną. Oczywiście jest to pewien skrót myślowy, jednak, jak sądzę dobrze oddaje współczesne tendencje.

\section{POSZUKIWANIE BEZPIECZEŃSTWA I JEGO KONSEKWENCJE DLA WSPÓŁCZESNEGO CZŁOWIEKA}

Człowiek XXI wieku, uwikłany w odnalezienie swojego miejsca we współczesnej, stale zmieniającej się rzeczywistości, z jednej strony stara się nadążyć za pędzącym światem, z drugiej strony potrzebuje normalności. Normalności, czyli życia opartego o pewne stałe i sprawdzone reguły. Dotyczy to całej sfery związanej z codzienną egzystencją, której wyznacznikiem jest poczucie stabilizacji. W szerszym rozumieniu stabilizacja dla każdego człowieka oznacza po prostu poczucie bezpieczeństwa, lub też inaczej - poczucie braku zagrożeń. Jak twierdzi R. Zięba, zagrożenie to „[...] pewien stan psychiki lub świadomości wywołany postrze- 
ganiem zjawisk, które oceniane są jako niekorzystne lub niebezpieczne" (Zięba 1997). A przecież właśnie bezpieczeństwo można określić jako „stan, który daje poczucie pewności i gwarancję jego zachowania oraz szansę na doskonalenie. To sytuacja odznaczająca się brakiem ryzyka [...]" (Słownik bezpieczeństwa 2009). Stąd też człowiek, starając się sprostać wyzwaniom współczesnego świata, podejmuje ryzyko, które ma doprowadzić go do szczęśliwego rozwiązania rozumianego jako uzyskanie właśnie stabilizacji.

Ryzyku zawsze towarzyszy poczucie lęku. Jak pisze B. Suchodolski: „życie rozpoczyna się od krzyku przerażenia, gdy człowiek opuszcza zaciszne łono matki i wstępuje w świat obcy, zimny, wrogi” (Suchodolski 1985). Podejmując ryzyko życia, narażamy się z jednej strony na lęk, z drugiej jednak dajemy sobie szansę na godne życie, zgodne z naszym oczekiwaniem. Oczywiście inną sprawą jest, czy nam się to uda czy nie. A zatem ryzyko jest wpisane w życie człowieka, stanowi stały element w praktycznie każdej sferze działalności ludzkiej. Jak twierdzi J. Wolanin „ryzyka nie da się uniknąć. Ryzyko rozpina przestrzeń, w której żyjemy. Jesteśmy zanurzeni w przestrzeni ryzyka. Ujawnia się ono na każdym kroku i w każdej chwili" (Wolanin 2009). Każdy człowiek posiada zatem umiejętność samodzielnego radzenia sobie z tym zjawiskiem. Jednak obecna rzeczywistość często stawia człowieka w sytuacji, gdzie nie jest on w stanie sprostać danej sytuacji. Szybkość następujących po sobie zdarzeń oraz konieczność błyskawicznej na nie reakcji wyzwala w człowieku poczucie obawy, że źle dokona wyboru; że nie ma wystarczających kompetencji w celu pozytywnego rozwiązania powstałej sytuacji. Brak wiedzy powoduje, że nad zachowaniem człowieka przejmują kontrolę automatyzmy. „Podejmując decyzję na temat czegoś lub kogoś, bardzo często opieramy ją nie na wszystkich dostępnych nam informacjach, lecz jedynie na jakimś pojedynczym fragmencie. Często jest to fragment ważny i dla decyzji istotny, ale ponieważ jest to tylko jeden, izolowany element, opieranie decyzji tylko na nim wystawia nas na niebezpieczeństwo popełnienia błędu" (Cialdini 2011). W takiej sytuacji można powiedzieć, że każda decyzja, nawet błędna, jest lepsza od jej braku. Jednak człowiek narażony jest na manipulacje i wpływy, przez co podejmuje decyzje, na które w sytuacji „normalnej” nigdy by się nie zdecydował. Ten brak poczucia pewności działania jest szczególnie istotny z punktu widzenia współczesnych społeczeństw.

Oczywistym jest, że w sytuacji niepewności decyzyjnej człowiek odczuwa lęk. „Lęk towarzyszący ryzyku jest tak samo stary, jak sam człowiek. Od czasów greckich przedstawiano człowieka, jako istotę zagrożoną przez bogów, przez ślepe siły przyrody, przez fatum" (Cialdini 2011). Jednak w obecnej sytuacji to odczucie jest coraz bardziej doznaniem patologicznym. W zmiennej rzeczywistości poczucie zagrożenia i lęku jest coraz większe, stopniowo przyjmując objawy choroby chronicznej. Pojawia się człowiek, którego osobowość przyjmuje cechy osobowości 
neurotycznej opisanej przez Karen Horney. Osobowość ta charakteryzuje się „strasznym uczuciem izolacji i bezradności w potencjalnie wrogim świecie” (Horney 1945). Przyczyną powstania takiej osobowości jest patologiczny lęk. „Lęk ten ma trzy komponenty: poczucie bezradności, wrogości i izolacji” (Horney 1945).

Współczesne środowisko społeczne ma charakter sieci, a interakcje między poszczególnymi członkami tej społeczności opierają się na wzajemnej ostrożności i niepewności. Taki charakter kontaktów zwielokrotnia i tak już wysoką wartość poziom lęku. Prowadzić to może do pojawienia się modelu społecznego zbliżonego do założeń rodziny neurotycznej. Wyróżnia się dwa modele rodziny neurotycznej, które można przypisać współczesnej społeczności jako przykłady mechanizmów radzenia sobie z lękiem:

- gdy dominują objawy lękowe: członkowie przeżywając silne uczucie zagrożenia, pokrywają swój lęk szczególnymi zabiegami psychohigienicznymi - pozornym ciepłem, komfortem - dążąc za wszelką cenę do uniknięcia otwartego konfliktu;

- gdy dominuje uczucie wrogości oraz silne poczucie braku zaufania: społeczność taka zamyka się, odgradza się od wpływów zewnętrznych, stosując mechanizmy izolacji i deprecjonując zjawiska spoza grupy osób zaufanych.

Oczywiście opisane wyżej techniki stanowią tylko pewien skrót czy analogię do uwarunkowań panujących w rodzinie. Jednak pewne prawidłowości rządzące grupami ludzkimi można w pewnych granicach traktować per analogia.

\section{PŁYNNE CZASY - W POSZUKIWANIU PUNKTÓW OPARCIA}

Skoro ryzyko i lęk stanowiły dla człowieka znane zjawiska, w jaki sposób radził on sobie do tej pory? Co stanowiło jego siłę w stawianiu czoła codziennym wyzwaniom? W moim przekonaniu istniały cztery elementy, do których człowiek mógł się odnieść, które były względnie stałe dla wyznaczania własnych decyzji i zamierzeń. Są to: normy moralne, autorytety, kultura, duchowość.

\section{NORMY MORALNE}

Umiejętność dostosowania się człowieka do wymagań środowiska społecznego powoduje jego akceptację oraz poczucie przynależności. Warunkiem jednak jest przyjęcie pewnych norm i wartości wyznawanych przez dane społeczeństwo. Osoba, która zinternalizowała wartości danej grupy, ma poczucie oparcia, jest silna siłą całej społeczności. Normy moralne miały za zadanie:

- regulować zachowania członków danej społeczności,

- organizować i wzmacniać doświadczenia społeczne danej grupy, 
- regulować realizację potrzeb grupy i jej poszczególnych członków.

W przypadku pojawienia się zaburzeń w obszarze norm moralnych (np. zjawisko anomii) pojawiają się opisywane przez Roberta Mertona rodzaje adaptacji w sytuacjach niepewności (Merton 2011, 19). Są to:

- innowacja - skupienie się na celach z pominięciem niektórych norm,

- rytualizm - ślepe przywiązanie do norm kosztem celów, choćby były one nieskuteczne w danej sytuacji,

- wycofanie - rezygnacja z celów i norm (życie z dnia na dzień),

- bunt - odrzucenie norm i wartości i stworzenie własnych (Pospiszyl 2008).

\section{AUTORYTETY}

Obecność autorytetów stawia człowieka w sytuacji, w której może on odnieść swoje postępowanie, myślenie czy zachowanie do pewnych wzorców, które wydają się być dla niego wiążące. Mogą one dotyczyć zarówno sytuacji życiowych (wzorce matki, ojca, babci), politycznych (charyzmatyczny przywódca), duchowych (ascetyczny duchowny) oraz każdej innej, która dotyczy życia człowieka. Autorytety wywierały nacisk na ludzi w celu wymuszenia konkretnego zachowania zgodnego z oczekiwaniami, bądź też zaniechania zachowania niepożądanego.

Współcześnie obecność autorytetu niesie ze sobą możliwości „oparcia się” o nie jako o gotowe wzorce zachowań. Z drugiej jednak strony taką postawą człowiek naraża się na zachowanie bezrefleksyjne, a co za tym idzie - może stać się ofiarą manipulacji, a w konsekwencji zostać wykorzystanym. O mnogości takich zdarzeń świadczą liczne doniesienia prasowe o oszustwach dokonywanych poprzez wykorzystywanie technik opartych na manipulacjach i wpływach społecznych.

W świecie pozbawionym prawdziwych autorytetów człowiek „łapie się” substytutów, które choć w niewielkim zakresie dają poczucie bezpieczeństwa podejmowanych decyzji. To właśnie wykorzystują specjaliści od wpływu społecznego, prezentując w środkach masowego przekazu wizerunek np. lekarza, który zachwala jakiś produkt. O właściwym wyborze danego produktu świadczyć ma właśnie substytut autorytetu pod postacią lekarza, który w dodatku jest zazwyczaj jedynie przebranym aktorem.

\section{KULTURA}

Jest ona rozumiana jako „całokształt materialnego i duchowego dorobku ludzkości, a także ogół wartości, zasad i norm współżycia przyjętych przez dane zbiorowości; wszystko to, co powstaje dzięki pracy człowieka, co jest wytworem jego myśli 
i działalności. Obecnie kulturę pojmuje się szeroko, tj. zarówno jako normy, wartości i wzory zachowań, jak i efekty oraz procesy tworzenia dóbr naukowych, artystycznych czy techniczno-cywilizacyjnych" (http://portalwiedzy.onet. pl/69310,,,,kultura, haslo.html.2014).

W obecnym świecie kultura nie jest już przyporządkowana do określonej grupy ludzi czy terytorium geograficznego. Płynność kultury związanej z uwarunkowaniami sieci wskazują na jej praktycznie nieograniczoność terytorialną, jak też na bliżej nieokreśloną liczbę przynależnych członków. Dziś nie ma znaczenia, gdzie mieszkasz i czym się zajmujesz. Ważne, żebyś „nadawał i odbierał” zgodnie ze wspólnym kluczem, żebyś był zalogowany i kompatybilny.

\section{DUCHOWOŚĆ}

Mówiąc o kulturze, nie sposób nie wspomnieć o religii. To z jej korzeni wyrosły wielkie kultury współczesnego świata. Do wartości religijnych odwołują się w dużej mierze wszystkie ważniejsze cywilizacje na świecie. Jest to zatem swoiste środowisko, w którym odbywa się całokształt życia człowieka.

Dualizm moralny spowodowany współistnieniem światów realnego i wirtualnego spowodował, że współczesny człowiek nie odnajduje w sobie potrzeby realizacji dogmatów wiary. Wszechobecna wolność w Internecie przekłada się na unikanie ograniczeń, którymi niewątpliwie są nauki religijne. Poszanowanie dogmatów wiary stało się nie tylko synonimem „ciemnogrodu”, ale stało się także obiektem krytyki, a nawet drwin. Pojawiły się religie internetowe, których założeniem jest przede wszystkich ukazanie, że człowiek może sam stworzyć sobie wiarę, boga i cały ceremoniał. Oczywiście nie ma on nic wspólnego z moralnością czy dogmatami wielkich religii świata. Przykładem takiej religii dla zabawy są pastafarianie. Ruch zapoczątkował Bobby Henderson. Złożył on protest przeciwko nauczaniu religii w szkołach w Stanach Zjednoczonych. Powołując się na równość wobec religii, wystosował pismo do Rady Edukacji z wnioskiem o możliwość nauczania na takich samych warunkach jak inne religie o Latającym Potworze Spaghetti jako stwórcy wszechświata. Zagroził on sankcjami prawnymi w sytuacji, gdy nauczanie innych religii ma mieć charakter obowiązkowy, a nie będzie mowy o LPS.

Jest to obecnie jedna $z$ najlepiej rozwijających się grup wyznaniowych na świecie, głównie poprzez sieci internetowe. 


\section{CZŁOWIEK W INTERNECIE}

Współczesny świat stawia człowieka w sytuacji, w której brakuje punktu odniesienia. Stare, sprawdzające się od pokoleń mechanizmy zawodzą wobec wyzwań współczesnego świata. Otwartość społeczeństwa w rozumieniu popperowskiego społeczeństwa otwartego jest niemożliwa do zrealizowania, a nawet wręcz niebezpieczna. Współczesne relacje międzyludzkie bardziej są zbliżone do wizji T. Hobbesa, który mówi, że „człowiek człowiekowi wilkiem i każdy był na wojnie z każdym" (Hobbes 1954).

Jak trafnie wskazuje E. Radwan, współczesny świat charakteryzuje upadek paradygmatów, a w szczególności dotyczącego wiary człowieka w „prawdziwość pewnych twierdzeń o świecie i jego logicznej przejrzystości. Paradygmat racjonalności i humanizmu, wizje szczęśliwych światów epoki oświecenia, nie są w stanie wyjść ze sfery idei do rzeczywistości, zwłaszcza politycznej i moralnej” (Radwan 2000).

Dezintegracja normatywna stała się faktem. W obecnym świecie człowiek musi sprostać dwóm moralnościom: jednej w świecie realnym, drugiej w wirtualnym.

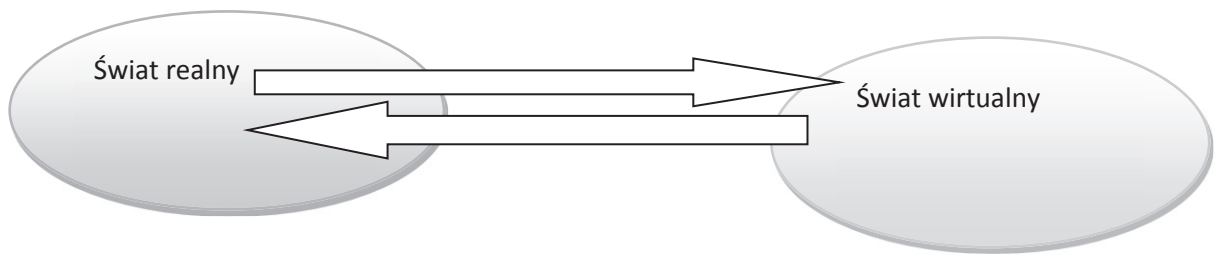

Rys. 1. Wzajemne zależności świata realnego i wirtualnego.

Opracowanie własne

O ile ta pierwsza jeszcze podlega pewnym hamulcom, to już ta druga jest niczym nie skrępowana. Wzajemne przenikanie się świata wirtualnego z rzeczywistym może w pewnych sytuacjach wpływać na postrzeganie świata jako całości. Ponieważ w Internecie „wszystko wolno”, każdy, kto „zanurza się” w świecie wirtualnym musi zdawać sobie sprawę z konsekwencji zagrożeń tam występujących. W świecie, gdzie nie ma żadnych ograniczeń, zachowanie człowieka cechuje zasada „wolności od”.

Kres autorytetów w świecie rzeczywistym stał się faktem. Naśladownictwo czy podatność na oddziaływania autorytetów znacznie się osłabiły. W obecnej rzeczywistości autorytety przyjmują bardziej hedonistyczne kształty, gdzie wartością są przede wszystkim przyjemności. Lansowany przez media wizerunek człowieka pokazuje zupełnie inne postawy społeczne niż te prezentowane przez poprzednie 
pokolenia, ale choć wzorce są dziś ukierunkowane na zmaksymalizowanie wolności i przyjemności, w konsekwencji powodują one zachwianie poczucia bezpieczeństwa, co bezpośrednio wpływa na niepewność statusu społecznego, brak intymności oraz obawy związane z autoprezentacją (Dziadzia 2007).

Upadek autorytetów to także kres pewnej epoki w zakresie kształcenia. Dziś przeciętnie zdolny młody człowiek może za pośrednictwem Internetu uzyskać i zweryfikować treści przekazywane mu przez „osoby godne zaufania”. I z pewnością zrobi do dokładniej i szerzej, niż gdyby polegał tylko na przekazie ustnym, choćby podczas wykładu na uczelni. Dziś autorytetami mogą być osoby, które świetnie poruszają się w zakresie wiedzy informatycznej. Haker mający umiejętność włamywania się do serwerów może stanowić atrakcyjniejszy wzór do naśladowania dla wielu młodych ludzi. Biorąc pod uwagę wzrastającą doniosłość zjawisk w Internecie, jest to stanowisko uzasadnione.

Ten dualizm światów ma swoje znaczenie także w odniesieniu do kultury. Tożsamość człowieka w dużej mierze dotyczy jego udziału w danej kulturze. Mieszczą się tu nie tylko poglądy na życie czy sposób zachowania, ale także inne manifestacje związane z określonym kręgiem kulturowym. Symbole czy godła stanowią o przynależności i pewnych cechach osób identyfikujących się z nimi. W erze globalizacji i zjednoczonej Europy, siła tych symboli osłabła. Pojęcia takie jak patriotyzm czy narodowość wymagają redefinicji. W obecnych uwarunkowaniach społeczno-politycznych pojęcie społeczeństwa jako całości przestaje mieć znaczenie. Jak słusznie twierdzi Z. Bauman „społeczeństwo w coraz większym stopniu postrzega się i traktuje raczej jako sieć niż strukturę: rozumie się je i postrzega jako sieć przypadkowych połączeń i blokad o zasadniczo nieskończonej liczbie możliwych permutacji” (Bauman 2007). Jeżeli więc kontakty interpersonalne charakteryzują się pewną przypadkowością i brakiem odniesienia do całości, z natury rzeczy stanowią ryzyko takich interakcji.

Przynależność do kultury sieci praktycznie alienuje człowieka, bo staje on nagle sam jeden wobec „całego świata wirtualnego”. To poczucie osamotnienia wzmacnia tylko poczucie niepewności i zagrożenia.

Po upadku bloku państw wschodnich uznano, że w dużej mierze kultury całego świata odwołają się do korzeni wywodzących się z religijnych dogmatów. Po 1990 roku można było wyodrębnić dziewięć głównych ośrodków kulturowych odwołujących się do religii (Huntington 2008). Były to: kultura zachodnia, latynoamerykańska, prawosławna, afrykańska, islamska, hinduistyczna, buddyjska, chińska, japońska.

Obecnie dostrzegany kryzys wiary świadczy o stopniowym odejściu od korzeni. Brak odwołania się do przynależności kulturowej (religijnej) stawia człowieka w sytuacji, w której może liczyć tylko na siebie. Jak pisze Z. Bauman: „wystawie- 
nie jednostki na kaprysy rynku towarów i pracy inspiruje i promuje podziały, a nie jedność, premiuje postawy konkurencyjne, degradując przy tym współpracę i zespołowe działanie do rangi tymczasowych taktyk, które należy zawiesić bądź porzucić, gdy tylko przestaną przynosić nam oczekiwane korzyści” (Bauman 2007).

Upadek autorytetów, dezintegracja normatywna, a w końcu odejście od wiary i kultury powoduje, że współczesny człowiek posiada ogromny margines wolności, ale nie czuje się we współczesnej cywilizacji ani bezpieczny, ani wolny (Bauman 2000).

Zmiany społeczno-polityczne zapoczątkowane w latach 90. XX wieku spowodowały, że na krótko pojawiło się poczucie pewnej stabilizacji i przewidywalności świata. Początkowo wydawało się, że człowiek potrafi właściwie rozeznać się w sytuacji i podjąć właściwe środki zaradcze przeciwko pojawiającym się zagrożeniom. S. Huntington stwierdził, że „najostrzejsze, najpoważniejsze i najgroźniejsze konflikty nie będą się między klasami społecznymi, biednymi i bogatymi czy innymi grupami zdefiniowanymi w kategoriach ekonomicznych, ale między ludami należącymi do różnych kręgów kulturowych” (Huntington 2008). Jednak, mimo że od napisania tych słów nie minęło zbyt wiele czasu, dziś już wiemy, że najbardziej prawdopodobnym miejscem wystąpienia konfliktów na skalę globalną jest świat wirtualny. Albert Einstein stwierdził kiedyś, że nie wie, na co zostanie rozegrana III wojna światowa. Czwarta miała się rozegrać na kamienie i kije. Dziś już wiemy, że III wojna światowa to przede wszystkim konflikt technologii w świecie wirtualnym (Świat Wiedzy 2011). Choć przecież nie brak zagrożeń militarnych, to nie wiemy, czy w Internecie III wojna światowa nie stała się już faktem.

Człowiek współczesny jawi się zatem jako istota oszołomiona, rozdarta i pozostawiona sama sobie bez możliwości oparcia. Brak odniesienia do większej wspólnoty oraz pojawienie się interakcji o charakterze spontanicznym spowodowały tylko dalszy wzrost zagrożenia.

\section{SPOŁECZEŃSTWO BEZPIECZEŃSTWA}

Człowiek XXI wieku cierpi na chroniczną potrzebę bezpieczeństwa. Samotny, zarówno w świecie realnym, jak i w sieci, stara się maksymalnie zmniejszyć swoje poczucie zagrożenia. Czyni to poprzez budowanie coraz to nowych systemów bezpieczeństwa, starając możliwie na bieżąco monitorować sytuację. O doniosłości tego zjawiska mogą świadczyć nagrody w licznych teleturniejach rozgrywanych w mediach. Dawniej nagrodę główną stanowiła rzecz użytkowa (pralka, telewizor, magnetofon itp.), dziś są to systemy antywirusowe najnowszej generacji oraz inne programy zapewniające nam bezpieczeństwo w sieci. Zachowanie takie jest uzasadnione, zważywszy na liczbę ataków hakerskich nie tylko na instytucje, ale 
także na osoby prywatne. O skali problemu świadczy podana przez Pentagon informacja, że „ataki hakerów będą traktowane jak działania wojenne, a Stany Zjednoczone odpowiedzą na nie zbrojnie" (Bauman 2000). Jednak każde nowe zabezpieczenie i każdy nowy zamek powodują, że „świat sprawia wrażenie jeszcze bardziej zdradliwego i przerażającego, i prowadzi nas do jeszcze bardziej obronnych zachowań, co z kolei, niestety, dodaje jeszcze więcej energii samonapędzającemu się mechanizmowi strachu" (Bauman 2000).

Współczesny postęp stał się „przyczyną bezsenności, pełnej koszmarów o pozostawaniu w tyle" (Bauman 2000). Postęp zatem to nie tylko rozwój, ale także wzrost poczucia zagrożenia. Pozostawanie w tyle oznacza także wystawienie się na ataki. Dziś świat wirtualny jest ściśle związany z realnym. Poprzez Internet możemy zostać okradzeni, ktoś może wykraść nasze tajemnice (dane wrażliwe) czy choćby tylko dokonać ingerencji w nasze zasoby informacyjne.

Analizując zatem potrzeby współczesnego człowieka, nie sposób nie zauważyć, że pojawiło się społeczeństwo, którego główną potrzebą - jak i celem - stało się przede wszystkim zapewnienie sobie maksymalnego bezpieczeństwa. To swoiste społeczeństwo bezpieczeństwa stawia potrzebę bezpieczeństwa na równi z potrzebami fizjologicznymi. Bo przecież czy w pewnych warunkach można myśleć o zaspokajaniu potrzeb fizjologicznych, nie zapewniwszy sobie najpierw bezpiecznych warunków życia?

Formułując tak postawioną tezę, należy stwierdzić, że być może - w odniesieniu do teorii potrzeb A. Maslowa - hierarchia potrzeb człowieka uległa pewnym modyfikacjom.

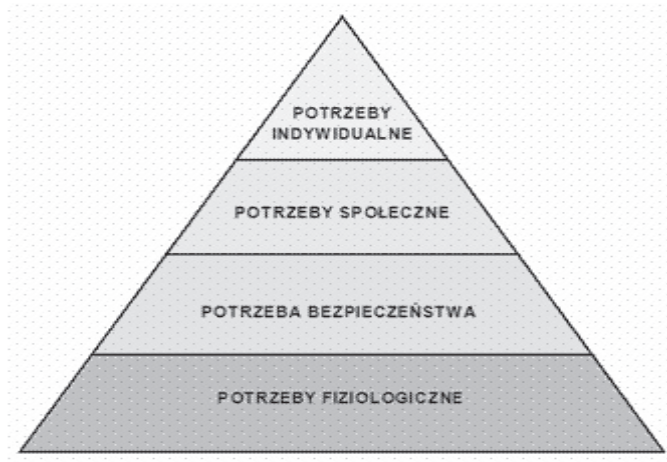

Rys. 2. Hierarchia potrzeb (Maslow 2006)

Uwarunkowania współczesnego świata spowodowały postrzeganie praktycznie wszystkich czynności i postaw ludzkich w kategorii bezpieczeństwa. Mówimy zatem bezpieczny seks, bezpieczna miłość, bezpieczne kontakty międzyludzkie. 
Bezpieczeństwo towarzyszy nam w każdym aspekcie życia człowieka. Stąd też w pewnym stopniu uzasadnione jest twierdzenie, że społeczeństwo funkcjonujące na zasadach obowiązujących w sieci jest społeczeństwem bezpieczeństwa, które:

- potrzeby bezpieczeństwa i fizjologiczne traktuje na tym samym lub podobnym poziomie,

- potrzeby społeczne i indywidualne uznaje za możliwe do realizacji jedynie poprzez kompatybilność ze społeczeństwem sieci, gdzie ich realizacja ogranicza się często jedynie do interakcji za pośrednictwem środków komunikacji elektronicznej.

Zasadne wydaje się więc przekonanie, że w dużej mierze potrzeby człowieka można sprowadzić do dwóch obszarów łączących w sobie poszczególne potrzeby. W obrębie potrzeb podstawowych, w moim przekonaniu, uzasadniony jest pogląd, że potrzeba bezpieczeństwa stanowi po prostu jedną $\mathrm{z}$ wielu potrzeb fizjologicznych. Nie sposób przecież roztrząsać w jakiej sytuacji, która z potrzeb będzie realizowana w pierwszej kolejności. Czy na przykład w sytuacji zagrożenia życia człowiek będzie myślał o innych potrzebach fizjologicznych niż o ratowaniu siebie? Z pewnością nie, ale po ustaniu zagrożenia będzie realizował inne potrzeby z obszaru podstawowych. Tak więc w praktycznie każdej sytuacji, w zależności od okoliczności, potrzeba bezpieczeństwa jak i inne potrzeby będą zhierarchizowane w kolejności możliwości „bezpiecznego” ich spełnienia.

Do podobnych wniosków doszedł A. Miller: „fakt, że bezpieczeństwo stanowi potrzebę podstawową wydaje się oczywisty po prostu na podstawie obserwacji" (Miller 2008). Uszeregował on podstawowe potrzeby w następujący sposób:

1. Potrzeba bezpieczeństwa - jako naczelna,

2. Potrzeba skuteczności i kontroli,

3. Potrzeba pozytywnej tożsamości,

4. Potrzeba więzi,

5. Potrzeba rozumienia rzeczywistości,

6. Potrzeba niezależności, czyli autonomii;

oraz bardziej zaawansowane podstawowe potrzeby:

1. Potrzeba długotrwałej satysfakcji,

2. Potrzeba transcendencji.

Pamiętając, że życie człowieka w XXI w przebiega dwutorowo (w świecie realnym i wirtualnym) należy odnieść te założenia do tych dwóch obszarów. Wydawać by się mogło, że inne potrzeby ma człowiek w świecie wirtualnym, a inne w świecie realnym. Jednak w moim przekonaniu, bez względu na „stan skupienia środowiska” potrzeby człowieka nie ulegają zmianie. Są tożsame bez względu na to, gdzie się poruszamy. W obu światach człowiek podobnie przeżywa swoje człowieczeństwo, choć oczywiście podlega innym uwarunkowaniom. 
B. Siemieniecki pisze, że we współczesnym środowisku człowieka „(...) występują następujące tendencje:

1. Poczucie alienacji w coraz szerzej otaczającym nas sztucznym świecie. Atomizacja postępująca w rodzinie, osłabiająca poczucie wpływania na los swój i innych.

2. Słabnące przystosowanie do zmieniającego się dynamicznie otoczenia. Powstawanie licznych napięć będących wynikiem zwiększonego dysonansu pomiędzy naturalnym rytmem życia a systematycznie przyspieszającymi zmianami współczesnej cywilizacji. Dysonans ów jest skutkiem nieprzystosowania biologicznego człowieka do gwałtownych zmian w otoczeniu społeczno-kulturowym, wywołanych nowymi technologiami.

3. Wzrost znaczenia wiedzy, co oznacza potrzebę coraz bardziej efektywnej edukacji nastawionej na człowieka, doskonalenie jego umiejętności twórczych, wyposażenie go w dużą wiedzę zawodową, ale przede wszystkim mądrość i zaradność.

4. Powszechne występowanie w procesie edukacyjnym nowoczesnych technologii informacyjnych.

5. Rosnąca racjonalizacja i technizacja życia, szybkie tempo zmian, pogoń za sukcesem, życie w czasie teraźniejszym, bez głębszej refleksji, spychanie na dalszy plan rozwoju duchowego człowieka.

6. Rosnące zakłócenia w komunikacji międzypokoleniowej, upadek autorytetów oraz zmniejszenie wrażliwości w stosunku do ludzi starych, słabych $\mathrm{i}$ chorych. Istotne zmiany $\mathrm{w}$ funkcjonowaniu rodziny.

7. Zwiększający się zakres ze strony nowoczesnych technologii komunikacyjnych.

8. Kryzys wzorców wartości humanistycznych, wzorców organizacji świata, paradygmatów cywilizacyjnych i religijnych" (Siemieniecki 2010).

Potrzeby człowieka są więc tożsame bez względu na to, czy znajduje się on $\mathrm{w}$ Internecie, czy też w świecie realnym.

Zdaniem Z. Baumana „[...] lęk przepełnia codzienną ludzką egzystencję, w miarę jak deregulacja dosięga coraz głębszych jej fundamentów, a ostatnie linie obrony społeczeństwa obywatelskiego ulegają rozpadowi” (Bauman 2007).

Potrzeby wyższego rzędu sformułowane przez A. Maslowa mają swoje uzasadnienie w życiu człowieka. Jednak do ich wystąpienia niezbędny jest czynnik, który zwykliśmy nazywać kompatybilnością, przez którą rozumiem możliwość nadania i odebrania komunikatu zarówno w świecie realnym, jak i wirtualnym.

Jak pisze R. Cialdini „[...] życie współczesne różni się od dawniejszego. Wskutek ogromnego postępu technologicznego mamy obecnie do czynienia z zalewem informacji, poszerzeniem liczby możliwości i stojących przed nami wyborów, 
z eksplozją wiedzy. Musimy się jakoś przystosować do tej lawiny zmian"(Cialdini 2011). Ilość informacji jakie docierają do człowieka powoduje, że nie ma on żadnej możliwości poddania wszystkich treści stosownej „obróbce myślowej”. W stale pędzącym świecie nikt nie ma czasu na analizowanie odebranych treści. Oczywiście naraża nas to na wszelakie manipulacje, $\mathrm{z}$ drugiej jednak strony chroni przed „przegrzaniem” naszego umysłu zbyt dużą ilością danych. Często jednak, aby w sposób selektywny odebrać istotne dla nas informacje, niezbędne są odpowiednie, kompatybilne urządzenia.

Współczesny człowiek nie wyobraża już sobie życia bez elektronicznych środków przekazu. Praktycznie każdy jest posiadaczem telefonu, komputera czy też innego urządzenia pozwalającego „być w sieci - w zasięgu”. Jak pisze H. Żuraw, współczesna medialność człowieka wiąże się z:

- korzystaniem z mediów,

- doświadczaniem ich wpływu - postrzeganiem, przetwarzaniem siebie i tworzeniem własnej osoby na nowo,

- stawaniem się komunikatem" (Żuraw 2001).

Stawanie się komunikatem, jak też przetwarzanie siebie, wymaga odpowiedniego kodu zarówno w zakresie nadawania, jak też odbioru. Kompatybilność jest zatem wymogiem niezbędnym i koniecznym, w celu zapewnienia człowiekowi prawidłowych relacji ze środowiskiem. Przenikanie się świata wirtualnego i realnego powoduje, że pewne zachowania stają się jednakowe dla obu obszarów. Szczególnie dotyczy to metod komunikowania się między ludźmi. Jak pisze T. Sosnowski, „komunikowanie się za pomocą komórki zaczyna zastępować komunikowanie się twarzą w twarz" (Sosnowski 2010).

Potrzeby społeczne i indywidualne związane są bezpośrednio z umiejętnością właściwej komunikacji przebiegającej w określonych warunkach. Dotyczy to zarówno zgodności sprzętowej, informatycznej, ale także np. bariery językowej. Rozmawiając twarzą w twarz człowiek „narażony jest” na wpływ rozmówcy. Postrzega jego zachowanie, analizuje mimikę twarzy oraz odbiera pozawerbalne sygnały. Prowadząc rozmowę poprzez komunikator, pozbawia się tego. Łatwiej zatem być bardziej stanowczym i przekazać informację, która w kontakcie osobistym byłaby trudna do wyartykułowania.

\section{ZAKOŃCZENIE}

Wkraczając w coraz bardziej zaawansowane technologicznie czasy, także potrzeby człowieka ulegają zmianom. W ogólnym zarysie pozostają takie same. Jednak sposób ich realizacji ulega zmianie. Skutki współczesnej cywilizacji są już nam znane. 
Mają one swoje uzasadnienie w teoriach katastrof, ryzyka czy chaosu. Pojmowanie coraz bardziej skomplikowanego świata staje się dla człowieka coraz trudniejsze, a przez to coraz bardziej zagrażające jego poczuciu odrębności i niepowtarzalności. W świecie, gdzie często jest się jedynie cyfrą czy bitem informacyjnym pozbawionym ludzkiego humanizmu, trudno zachować obojętność. Podobnego zdania jest M. Goliszyńska-Pieszyńska, która mówi już o erze posthumanistycznej (Goliszyńska-Pieszyńska 2009). Wszystko to powoduje, że dzisiejszy świat niesie ze sobą wiele zagrożeń, które zwykły obywatel może jedynie przeczuwać, ale z całą pewnością może i ma prawo się ich bać. Proroczo brzmi zatem twierdzenie Zygmunta Freuda, że człowiek kultury zamienił poczucie szczęścia na poczucie bezpieczeństwa (Freud 1998).

Jesteśmy zatem społeczeństwem bezpieczeństwa, ale bardziej w rozumieniu obaw o nasze jutro, naszą przyszłość w czasach płynnych i niepewnych. Paradoksalnie, im więcej bezpieczeństwa w naszym otoczeniu, tym mniej pewności i szczęścia, które przecież jest tak istotne w życiu każdego człowieka.

\section{BIBLIOGRAFIA:}

B. Balcerowicz., 2009, Słownik terminów z zakresu bezpieczeństwa narodowego, AON,Warszawa

Bauman Z., 2007, Płynne czasy. Życie w epoce niepewności. Wydawnictwo SIC!, Warszawa.

Bauman Z., 2000, Ponowoczesność jako źródło cierpień. Wydawnictwo Sic!, Warszawa. Cialdini R., 2011, Wywieranie wplywu na ludzi. Teoria i praktyka. Gdańskie Wydawnictwo Psychologiczne, Gdańsk.

Dziadzia B., 2007, Wplyw mediów. Konteksty społeczno-edukacyjne. Wydawnictwo Impuls, Kraków.

Freud Z., 1998, Kultura jako źródło cierpień. KR. Warszawa

Goliszyńska-Pieszyńska M., 2009, Polityka wiedzy a współczesne procesy innowacyjne. Wydawnictwo Scholar, Warszawa.

Hobbes T., 1954, Lewiatan czyli materia, forma i władza państwa kościelnego i świeckiego. PWN, Warszawa.

Horney K., 1993, Neurotyczna osobowość naszych czasów, PWN, Warszawa. Huntington S., 2008, Zderzenie cywilizacji. Wydawnictwo Literackie Muza, Warszawa. Maslow A., 2006, Motywacja i osobowość. Wydawnictwo Naukowe PWN, Warszawa. Merton R.,2011,Teoria socjologiczna i struktura społeczna, PWN, Warszawa Miller A., 2008, Dobro i zło z perspektywy psychologii społecznej. Wydawnictwo WAM, Kraków. 
Pospiszyl I., 2008, Patologie społeczne. Wydawnictwo Naukowe PWN, Warszawa.

Radwan E., 2000, Problemy filozofii pedagogiki bezpieczeństwa. W: Bezpieczeństwo personalne i strukturalne wobec wyzwań współczesnego świata. AON, Warszawa. Siemieniecki B., 2010, Pedagogika medialna - następca edukacji medialnej. W: Edukacja medialna. Nadzieje i rozczarowania, M. Sokołowski (red.). Wydawnictwo Comandor, Warszawa.

Sosnowski T., 2010, Kompetencje medialne dotyczace korzystania z telefonu komórkowego nowym wyzwaniem edukacji medialnej. W: Edukacja medialna. Nadzieje i rozczarowania, M. Sokołowski (red.). Wydawnictwo Comandor, Warszawa.

Suchodolski B., 1985, Kim jest człowiek. Wiedza Powszechna, Warszawa.

Wolanin J., 2009, Bezpieczeństwo i ryzyko a polityka. W: Bezpieczeństwo wewnętrzne państwa. Wybrane zagadnienia, S. Sulowski, M. Brzeziński (red.). Dom Wydawniczy Elipsa, Warszawa.

Zięba R., 1997, Kategoria bezpieczeństwa w nauce o stosunkach międzynarodowych. $\mathrm{W}$ : Bezpieczeństwo narodowe i międzynarodowe u schyłku XX wieku, D.B. Bobrow, E. Haliżak, R. Zięba (red.). Instytut Stosunków Międzynarodowych UW, Warszawa. Zuraw H., 2001, Medialność człowieka. Medialność kultury. W: Wyzwania pedagogiki medialnej - nowe perspektywy XXI w, M. Sokołowski (red.). Wydawnictwo Kastalia, Olsztyn.

„Świat Wiedzy” 5/2011.

http://portalwiedzy.onet.pl/69310,,,,kultura,haslo.html 2014

\title{
THE SECURITY SOCIETY AS CONSEQUENCES OF LIFE IN LIQUID TIMES
}

\begin{abstract}
The article discusses the issue of attitudes and behaviors of the $21^{\text {st }}$-century man in the perspective of the threats of the modern world, resulting from the conditions of the "network society". The importance of security, as the main human need, in the context of socio-political changes at the turn of the $20^{\text {th }}$ and $21^{\text {st }}$ centuries and rapidly developing information technologies, constitutes a pretext to formulate the thesis about the emergence of a specifically shaped security society. This paper is an attempt to understand the attitudes and behaviors of modern man, with particular emphasis on the conditions related to the changing social reality.
\end{abstract}

Keywords: security, human attitudes, security society, Internet, virtual world, threats 